\title{
SLC22A2 wt Allele
}

National Cancer Institute

\section{Source}

National Cancer Institute. SLC22A2 wt Allele. NCI Thesaurus. Code C107575.

Human SLC22A2 wild-type allele is located in the vicinity of $6 q 25.3$ and is approximately $107 \mathrm{~kb}$ in length. This allele, which encodes solute carrier family 22 member 2 protein, plays a role in mediating tubular uptake of org anic compounds from the circulation. 